\title{
Analgesic and antibutyrylcholinestrasic activities of the venom prepared from the Mediterranean jellyfish Pelagia noctiluca (Forsskal, 1775)
}

\author{
Yosra Ayed ${ }^{1}$, Afef Dellai ${ }^{2}$, Hedi Ben Mansour ${ }^{2}$, Hassen Bacha ${ }^{1,3^{*}}$ and Salwa Abid ${ }^{1}$
}

\begin{abstract}
Background: Toxins derived from jellyfishes have been exploited as a model for the development of new drug promising applications to treat neurodegenerative diseases. The present work is aimed to evaluate the acute toxicity of crude venom of Pelagia noctiluca and then to screen the analgesic and antibutyrylcholinestrasic (anti-BuChE) activities of the crude venom and its fractions.
\end{abstract}

Methods: Sephadex G75 gel was used to separate crude venom of Pelagia noctiluca, which led to some fractions. In addition, in vivo analgesic and in vitro plasma antibutyrylcholinestrasic activities were carried out with Pelagia crude venom and its fractions respectively.

Results: The crude venom and its fractions displayed analgesic and anti-BuChE activities at different doses without inducing acute toxicity. Fraction 2 possesses the highest analgesic and antibutyrylcholinestrasic properties. The crude venom and fraction 1 had shown to possess less significant inhibitory activity against analgesic and antibutyrylcholinestrasic models.

Conclusions: Based on this study, the crude venom of Pelagia noctiluca is found to be a useful tool for probing pharmacological activity. The purification and the determination of chemical structures of compounds of active fractions of the venom are under investigation.

Keywords: Pelagia noctiluca, Venom, Jellyfish, Analgesic activity, Anti-Butyrylcholinesterasic activity

\section{Introduction}

Cnidarians are the largest phylum of generally toxic animals. Their toxins and venoms have not received as much scientific attention as those of many terrestrial (snakes, scorpions, spiders, etc.) and some marine animals (i.e. cone snails) [1].

The jellyfish, Pelagia noctiluca (P. noctiluca) [2] is a cnidarian of the class Scyphozoa, the order Semaestomeae, and the family Pelagiidae. It is widely distributed in different parts of the Mediterranean Sea [3-5] and in the Atlantic Ocean [6]. As a member of the phylum

\footnotetext{
* Correspondence: hassen-bacha@fmdm.rnu.tn

1'Laboratory for Research on Biologically Compatible Compounds (LRSBC),

Faculty of Dentistry, Monastir university, Rue Avicenne, 5019, Monastir,

Tunisia

${ }^{3}$ University of Jendouba, Cité AlFaeiz rue Jamil Boutheina, Jendouba 8100,

Tunisia

Full list of author information is available at the end of the article
}

Cnidaria, their main characteristic is the specialized cells (cnidocytes) harbouring cnidocysts. Cnidocysts, or nematocysts, contain a complex mixture of highly active and structurally diverse toxins. The cnidocyst capsules are discharged as a response to adequate chemical and mechanical stimuli elicited by prey organisms [7].

The venom of $P$. noctiluca is of protein nature and contains peptides. It is antigenic and possesses dermonecrotic and hemolytic properties [8]; Cytolytic and neurotoxic effects have also been shown by several biological assays [9-12].

Since 1960, Scientists have studied on the biochemistry, pharmacology and toxicology of jellyfish venom and most of them have tried to extract its active components as a new natural source of drugs. There are several reports on the antimicrobial activities of the jellyfish extracts, which can afford design of new antibiotics with broad-spectrum antimicrobial activity. Ovchinnikova et

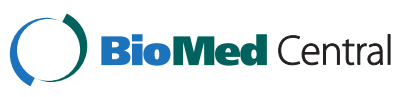


al [13] have discovered a new antimicrobial peptide, termed aurelin, from a scyphoid jellyfish Aurelia aurita. This Anti-microbial peptide exhibited activity against Gram positive and Gram-negative bacteria [13]. Thangaraj et al [14] have studied the antimicrobial activity of the crude extract of Stichodactyla gigantea and Stichodactyla mertensii. The two sea anemone extracts exhibited significant activity against all bacterial strains. Williams et al [15] have reported that the tissue extract of Stichodactyla haddoni showed highly antimicrobial activity. Synthetic amino-terminal peptides from the sea anemone Stychodactyla helianthus have shown cytolytic activity to human erythrocytes and antibacterial activity against Escherichia coli and Staphylococcus aureus [16]. It was also reported that jellyfish venom could have promising applications in cardiovascular medicine [17]. So, it is useful to study jellyfish venom for the sake of the human health. Some experiments in rats showed that jellyfish can be used to cure arthritis, back pain and to remedy fatigue [18].

In this regard, our objective in this study was to establish a procedure for extraction of $P$. noctiluca crude venom, to evaluate the acute toxicity, then, to screen the analgesic and anti-BuChE activities of the crude venom and its fractions.

\section{Materials and methods Chemicals}

Lysine acetylsalicylate (ASL) was obtained from Sanofi Winthrop Pharmaceuticals (Morrisville, PA, USA). Acetic acid (glacial) was obtained from Sigma Chemical Co. (St. Louis, MO, USA). Butyrylthiocholine iodide was purchased from Quimica Clinica Aplicada S.A. (Amposta, Spain). All other chemicals used were of analytical grade.

\section{Preparation of nematocysts}

Specimens of $P$. noctiluca were collected from the beach of Monastir, Tunisia, in May 2010, and were identified by Professor Mohamed Nejib Daly Yahia from Faculty of Sciences of Bizerte, (Bizerte, Tunisia). The tentacles were excised manually from living specimens as soon as possible after capture and were then immediately frozen at $-20^{\circ} \mathrm{C}$.

The nematocysts isolation method has been previously described by Arillo et al [19]. Tentacles were submerged in distilled water for $5 \mathrm{~h}$ at $4^{\circ} \mathrm{C}$. The ratio of organic tissue to distilled water was approximately 1:5. After a complete detachment of the epidermis the tissue was removed from the suspension containing both epidermis and undischarged nematocysts deriving from the osmotic rupture of nematocysts. The nematocysts, attached to the epidermal tissue, were separated by stirring. The nematocysts suspension was repeatedly washed in distilled water and filtered through plankton nets (100, 60 and $40 \mu \mathrm{m}$ mesh, respectively) to remove most of the tissue debris, and then centrifuged at $4^{\circ} \mathrm{C}$ (ALC PK $120 \mathrm{R}, 4000 \mathrm{~g}$ for $5 \mathrm{~min})$. The content, purity and integrity of nematocysts (cnidocysts) were controlled microscopically, and the concentrate nematocysts were stored at $-80^{\circ} \mathrm{C}$ until further use [20].

\section{Nematocysts lysis and protein extraction}

Crude venom was extracted by sonication on ice (Sonoplus, $70 \mathrm{mHz}, 30$ times, 20s) of nematocysts as described by Marino et al [20]. After sonication, the suspension was centrifuged at $11,000 \mathrm{rpm}$ for $5 \mathrm{~min}$ at $4^{\circ} \mathrm{C}$. The supernatant was carefully removed, filtered and lyophilized.

\section{Protein determination}

The protein content of the crude venom was determined according to the Bradford method (BioRad Labs, Hercules, CA) [21]. In the following, all mention of "venom and fractions concentrations" refers to protein concentration expressed in units of $\mu \mathrm{g} \mathrm{ml}^{-1}$.

\section{SDS-PAGE}

Protein species were observed by polyacrylamide gel electrophoresis (SDS-PAGE) as described previously [22]. Jellyfish crude venom protein $(200 \mu \mathrm{g})$ were diluted (1:1) with sample buffer (50 mM Tris pH 6.8, 2\% SDS, $20 \%$ glycerol, 2\% 2-mercaptoethanol and $0.04 \%$ bromophenol blue) and were then boiled for $3 \mathrm{~min}$. Running gels of $5 \%$ acrylamide and stacking gels of $12 \%$ acrylamide were used. The gels were stained with Coomassie R-250. The molecular size marker, 6-170 kDa (protein standards, Invitrogen, CA, USA), was run parallel with crude venom sample for molecular weight estimation.

\section{Size exclusion chromatography}

About $300 \mathrm{mg}$ of crude venom of $P$. noctiluca was dissolved in filtered-degassed double-distilled water. After centrifugation at $17000 \mathrm{~g}$ for $15 \mathrm{~min}$ at $4^{\circ} \mathrm{C}$, the supernatant was loaded on Sephadex G-75 gel-filtration chromatography columns (2.6 x $100 \mathrm{~cm}$; Pharmacia), previously equilibrated with $200 \mathrm{mM}$ ammonium acetate, $\mathrm{pH} 6.8$ and eluted under the same conditions. The flow rate was $3 \mathrm{ml} / \mathrm{min}$ using a Bio-Rad 2110 fraction collector and the elution of the proteins was monitored at $280 \mathrm{~nm}$ by an ultraviolet detector.

\section{Animals}

Swiss albino mice (weighing 18-25 g) of both sexes were obtained from Pasteur institute (Tunis, Tunisia). They were housed in polypropylene cages and were left for 1 week under constant conditions of temperature $\left(22 \pm 2^{\circ}\right.$ C) and a light/dark cycle of $12 \mathrm{~h} / 12 \mathrm{~h}$. Animals had free 
access to standard pellet diet and water ad libitum. Housing conditions and in vivo experiments were approved according to the guidelines established by the European Union on Animal Care (CFE Council (86/ 609)). The mice were used for the acute toxicity testing and for the analgesic investigation. Animals were divided into drug-treated 'test' and saline-treated 'control' groups of six or eight animals per group.

\section{Acute toxicity}

For acute toxicity, mice were divided into groups of eight animals each. One group served as a control and received $0.9 \% \mathrm{NaCl}$ alone $(10 \mathrm{ml} / \mathrm{kg})$ given intraperitoneally (i.p.), while the remaining groups were treated with increasing doses of $P$. noctiluca venom: $1,5,10,20,30$, 40 and $50 \mathrm{mg} / \mathrm{kg}$ (i.p.), respectively. The mortality rate within a $48 \mathrm{~h}$ period was determined and the LD50 (the amount required to kill $50 \%$ of animals) was estimated according to the method described by Miller and Tainter [23]. According to the results of acute toxicity test, doses were chosen for pharmacological evaluations. After the last observation the mice were killed and the liver, lungs, heart, spleen and kidneys were withdrawn and stocked for next evaluations.

\section{Analgesic activity}

Analgesic activity was performed according to the method of Koster et al [24] and assessed by the acetic acid abdominal constriction test (writhing test), a chemical visceral pain model. Swiss albino mice were selected 1 day prior to each test and were divided into groups of six mice each. One group served as the control and was pretreated under cutaneously with $10 \mathrm{ml} / \mathrm{kg}$ of saline. Another group was pretreated with the reference drug, acetyl salicylate of lysine (ASL), $200 \mathrm{mg} / \mathrm{kg}$, by the same route. The remaining groups were injected intraperitoneally with $10 \mathrm{ml} / \mathrm{kg}$ of $1 \%$ acetic acid solution $30 \mathrm{~min}$ after the administration of the crude venom of $P$. noctiluca and its two fractions at the doses of 1 and $2 \mathrm{mg} / \mathrm{kg}$ b.w. (body weight); after acetic acid administration, the number of writhes was counted during $30 \mathrm{~min}$. Antinociceptive activity was expressed as inhibition percent of the usual number of writhes observed in control animals. The percentages of inhibition were calculated according to the following formula: \% inhibition $=(($ number of writhes) $)_{\text {control }}$-(number of writhes) $)_{\text {treated }}$ group $) \times 100 /\left(\right.$ number of writhes) control $_{\text {. }}$

\section{In vitro Butyrylcholinesterase inhibition assay Human plasma preparation}

Human blood from anonymous healthy male subject (27 years) was provided by the Hospital of Monastir in Tunisia. Blood was collected in EDTA treated $(1 \mathrm{mg} / \mathrm{ml})$ glass tubes, the red blood cells were eliminated by centrifugation at $2000 \mathrm{~g}$ for $10 \mathrm{~min}$, the plasma (supernatant) was then recuperated and diluted $(1 / 200)$ with $50 \mathrm{mM}$ phosphate buffer $(\mathrm{pH}=7.4)$. Plasma was used immediately for studying butyrylcholinesterase activity or conserved at $2-8^{\circ} \mathrm{C}$ (stable for 7 days).

\section{Butyrylcholinesterase inhibition assay}

Butyrylcholinesterase (BuChE) inhibiting activity was measured by the spectrophotometric method previously reported by Ellman et al [25], modified by Ortega et al [26] and adapted according to our experimental conditions. Butyrylthiocholine iodide was used as substrate to assay butyrylcholinesterase activity. In order to calculate the activity of the obtained butyrylcholinesterase, the following procedure was employed: $1.5 \mathrm{ml}$ of phosphate buffer $50 \mathrm{mM} \mathrm{pH}=7.2$, containing $0.26 \mathrm{mM}$ of $5,5^{\prime}$ dithiobis-2- nitrobenzoic acid (DTNB), $10 \mu \mathrm{l}$ of human plasma and $10 \mu \mathrm{l}$ of the crude venom of $P$. noctiluca and the tested fractions $(1,10$ and $100 \mu \mathrm{g} / \mathrm{ml}$ as final concentrations) were placed in a microcuvette, which was incubated for $15 \mathrm{~min}$ at $30^{\circ} \mathrm{C}$. The hydrolysis of butyrylthiocholine was monitored by the formation of yellow 5-thio-2-nitrobenzoate anions resulting from the reaction of DTNB with the thiocholine released by the enzymatic hydrolysis of butyrylthiocholine. Absorbance was measured using an M350 double Beam UV-VIS spectrophotometer "Camespec" at $405 \mathrm{~nm}$, and the reading was repeated during $75 \mathrm{~s}$ at intervals of $30 \mathrm{~s}$ to verify the linearity of the reaction. The enzymatic activity was calculated using the absorption coefficient 23460 and according to the relation:

$$
\begin{aligned}
& \text { Enzymatic activity }(\mathrm{UI}(\text { international units }) / \mathbf{l}) \\
& =23460 \times\left(\mathrm{DO}_{405 \mathrm{~nm}} \mathrm{t}_{0 \mathrm{~s}}-\mathrm{DO}_{405 \mathrm{~nm}} \mathrm{t}_{75 \mathrm{~s}}\right)
\end{aligned}
$$

The percentage (\%) of inhibition of BuChE activity was calculated as follows: $(E-S) / E \times 100$. Where $E$ is the activity of the enzyme without test compound (in our case $E=9000 \mathrm{UI} / \mathrm{l}$ ) and $\mathrm{S}$ is the activity of enzyme with test compound.

$\mathrm{IC}_{50}$ (concentrations of test compounds that inhibited the hydrolysis of substrate (butyrylthiocholine) by $50 \%$ ) values were calculated from dose-inhibition curves [27]. All experiments were repeated three times.

\section{Statistical analysis}

Data were expressed as the mean \pm standard deviation of three independent experiments. The statistical analyses were performed with SPSS ${ }^{\text {m }}$ software v.10.0 (from SPSS Inc.). Data were analyzed for statistical significance using Dunnett's test. 


\section{Results}

\section{SDS-PAGE of $P$. noctiluca Crude venom}

Electrophoretical analysis of $P$. noctiluca crude venom revealed a number of bands of varying size (Figure 1). 15 bands appeared after staining of the SDS-PAGE gel. The molecular weights of these bands were $4 ; 14 ; 16 ; 20 ; 29$ ; 33 ; 37 ; 45 ; 55 ; 64; 66 ; 70 ; 80 ; 115 and $120 \mathrm{kDa}$,

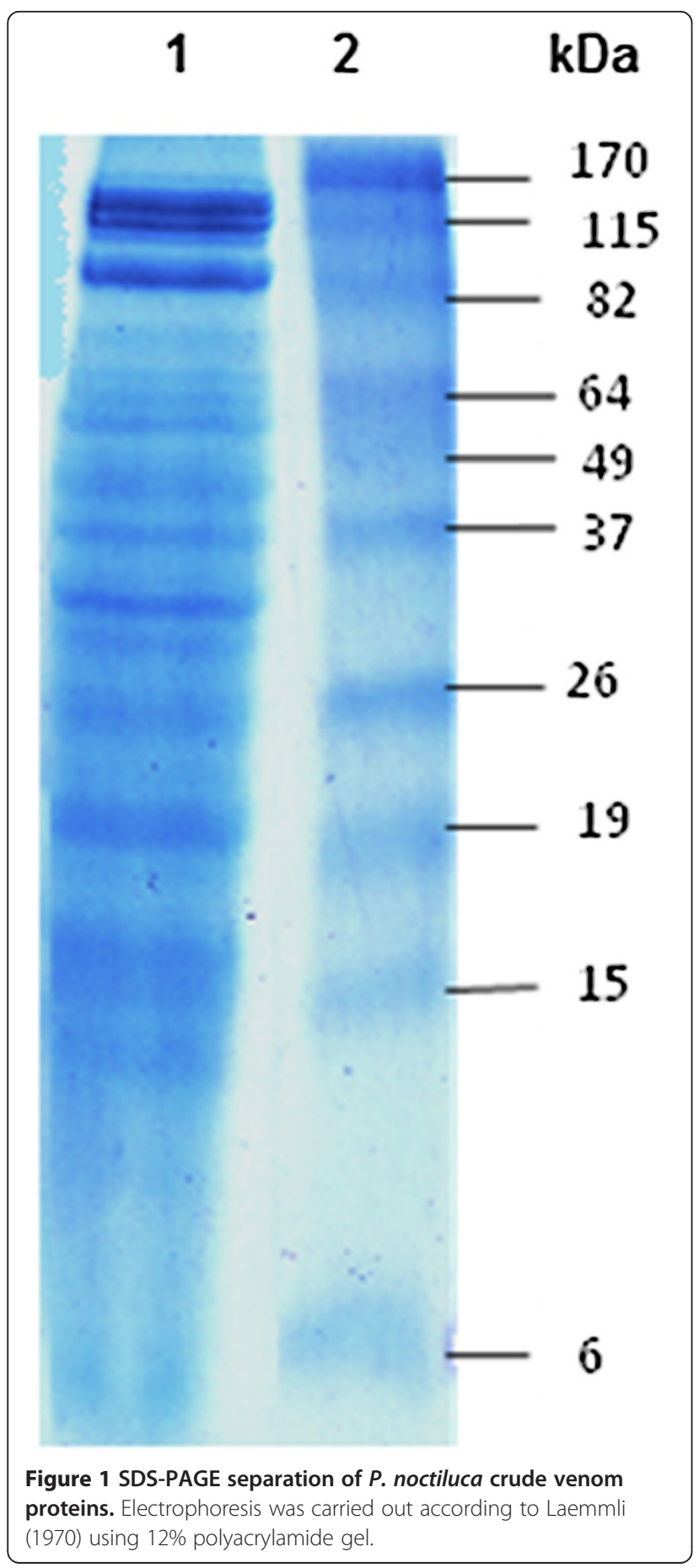

respectively. The protein components of jellyfish crude venom were complex.

\section{Sephadex G-75 chromatography}

Proteins with molecular weights greater than $70 \mathrm{KDa}$ are completely excluded. About $200 \mathrm{mg}$ of crude venom of $P$. noctiluca were applied to a column packed with Sephadex G-75 (Pharmacia, Uppsala, Sweden) at a flow rate of $18 \mathrm{ml}$ per hr gave rise to two peaks in the elution profile monitored at $280 \mathrm{~nm}$ (Figure 2). The two peaks were collected and named fraction 1 (F1) and fraction 2 (F2).

\section{Toxicity studies}

Swiss albino mice were observed during $48 \mathrm{~h}$ and morbidity and/or mortality were recorded, for each group at the end of observation period. The LD50 of the crude venom was about $20 \mathrm{mg} / \mathrm{kg}$ b.w.

\section{Analgesic activity}

The inhibition percentages of writhing for $P$. noctiluca crude venom and its two fractions (F1 and F2) are shown in Table 1. The reference drug acetyl salicylate of lysine (ASL) inhibited $61.88 \%$ of the number of writhing elicited by acetic acid. The analgesic effect was tested using the crude venom, F1 and F2 at the concentrations of 1 and $2 \mathrm{mg} / \mathrm{kg}$ b.w. The administration of all tested extracts induced a dose-dependent antinociceptive activity on Swiss albino mice. F2 possesses the highest analgesic properties, at $2 \mathrm{mg} / \mathrm{kg} \mathrm{b}$. w. (83.15\%). The crude venom of $P$. noctiluca was also active; the percentage of inhibition of writhing was $77.89 \%$ at $2 \mathrm{mg} / \mathrm{kg} \mathrm{b}$. w. The lowest activity was observed with F1.

\section{In vitro butyrylcholinesterase inhibition effect}

Results of human plasma BuChE inhibitory activity of the crude venom of $P$. noctiluca and its fractions are shown in Table 2. The crude venom and its fractions were found to inhibit the BuChE activity. The inhibition was immediate, as evidenced by the linearity of the absorbance vs. time during the $75 \mathrm{~s}$ assay period ( $\mathrm{r} 2>0.978)$. The inhibition level of BuChE activity increased significantly in presence of F2 compared to the crude venom of $P$. noctiluca. At the highest concentration $(100 \mu \mathrm{g} / \mathrm{ml})$ of F2 and the crude venom, the inhibition was $68 \% \pm 4.25$ and $56.44 \% \pm 2$ respectively. The determined $\mathrm{IC}_{50}$ were respectively 58 and $75.5 \mu \mathrm{g} /$ $\mathrm{ml}$ for F2 and the crude venom. However, F1 was the least effective as inhibitor of enzymatic activity.

\section{Discussion}

A large number of marine organisms are known to posses bio-active substances that have tremendous pharmaceutical potential for the future [28]. However, considerable 


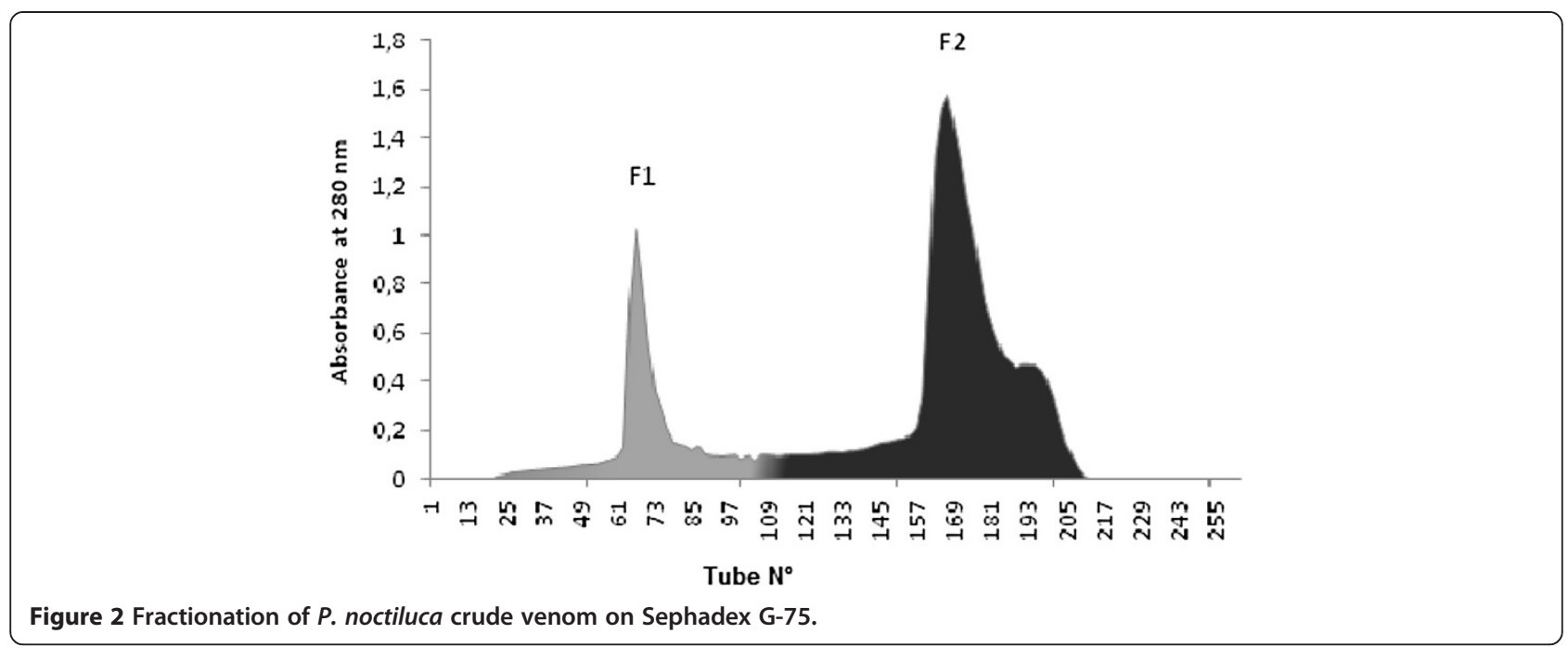

progress has been made to isolate and characterize the toxic components of marine cnidarians [29-32]. Several antimicrobial peptides have been isolated from Cnidaria [13-16]. To our knowledge, no antimicrobial activity of $P$. noctiluca venom has been reported.

Fortunately, we could obtain adequate $P$. noctiluca material because of the exceptional abundance of this jellyfish in the coastal water of Tunisia, in these recent years. The extraction of crude venom from nematocysts is essential before any research into crude venom toxicity can be conducted.

In an attempt to obtain crude venom from the nematocysts of $P$. noctiluca, we tried some mechanical methods including sonication, which did not destroy $P$. noctiluca nematocysts [33-35].

In the present study, Protein components of $P$. noctiluca nematocysts crude venom were determined by using SDS-PAGE on $12 \%$ polyacrylamide gel. 15 distinct clear bands were determined with molecular weight of 4 ; $14 ; 16 ; 20 ; 29 ; 33 ; 37 ; 45 ; 55 ; 64 ; 66 ; 70 ; 80 ; 115$ and $120 \mathrm{kDa}$ in $P$. noctiluca crude venom (Figure 1 ). It

Table 1 Analgesic activity of $P$. noctiluca crude venom, its two fractions (F1 and F2) and the reference drug (ASL)

\begin{tabular}{llcl}
\hline Groups & $\begin{array}{l}\text { Dose } \\
(\mathbf{m g} / \mathbf{k g})\end{array}$ & $\begin{array}{l}\text { Number of } \\
\text { writhes }\end{array}$ & $\begin{array}{l}\text { Inhibition of } \\
\text { writhing (\%) }\end{array}$ \\
\hline Control & - & $95 \pm 8.4$ & - \\
\hline Venom & 1 & $57 \pm 4.2^{* *}$ & 40 \\
\hline Fraction 1 & 2 & $21 \pm 2.8^{* *}$ & 77.89 \\
\hline Fraction 2 & 1 & $35 \pm 4.2^{* *}$ & 63.15 \\
\hline Reference drug (ASL) & 2 & $10 \pm 2.8^{* *}$ & 89.47 \\
\hline Va & 1 & $16 \pm 1.4^{* *}$ & 83.15 \\
\hline
\end{tabular}

Values are expressed as mean \pm S.E.M. (Standard Error of the Mean) $(N=6)$; $A S L$ : acetyl salicylate of lysine. Significant difference obtained with: ${ }^{* *} \mathrm{P}<0.01$. has been reported that toxic fractions of $P$. noctiluca crude venom has a molecular weight of 54, 92, 130 and $150 \mathrm{kDa}[36]$.

Separation of crude crude venom of $P$. noctiluca was achieved by a size exclusion chromatography (sephadex $\mathrm{G}$ 75). This gel is a dextran capable of separating proteins with molecular weights between 3 and $70 \mathrm{KDa}$. The volume outside the gel matrix is known as the void volume (Vo). This is the volume required to elute a substance so large that it cannot penetrate the pores at all. Proteins with molecular weights greater than $70 \mathrm{KDa}$ are completely excluded. Two peaks were collected and

Table 2 Percentage of inhibitions of butyrylcholinesterase activity by: $P$. noctiluca crude venom and its two fractions (F1 and F2)

\begin{tabular}{|c|c|c|c|}
\hline & $\begin{array}{l}\text { Concentration } \\
(\mu g / \mathrm{ml})\end{array}$ & $\begin{array}{l}\text { Inhibition (\%) } \\
\text { against } \\
\text { BuChe }\end{array}$ & $\begin{array}{l}\mathrm{IC}_{50} \\
(\mu g / \\
\mathrm{ml})\end{array}$ \\
\hline \multirow[t]{3}{*}{ Venom } & 1 & $19.51 \pm 1.20^{*}$ & \multirow[t]{3}{*}{77.5} \\
\hline & 10 & $29.5 \pm 1.2^{*}$ & \\
\hline & 100 & $56.44 \pm 2^{*}$ & \\
\hline \multirow[t]{3}{*}{ F1 } & 1 & $10.2 \pm 2.5^{*}$ & \multirow[t]{3}{*}{82} \\
\hline & 10 & $24 \pm 4.25^{*}$ & \\
\hline & 100 & $54.16 \pm 1.5^{*}$ & \\
\hline \multirow[t]{3}{*}{$\mathrm{F} 2$} & 1 & $12.35 \pm 0.75^{*}$ & \multirow[t]{3}{*}{58} \\
\hline & 10 & $32.25 \pm 2.35^{*}$ & \\
\hline & 100 & $68 \pm 4.25^{*}$ & \\
\hline \multirow{3}{*}{$\begin{array}{l}\text { (a) } \\
\text { Galanthamine }\end{array}$} & 1 & $44.5 \pm 1.00^{* *}$ & \multirow[t]{3}{*}{7.9} \\
\hline & 10 & $59.44 \pm 2.5^{* *}$ & \\
\hline & 100 & $67.5 \pm 2.5^{*}$ & \\
\hline
\end{tabular}

Significant difference obtained with: ${ }^{*} P<0.05$ : ${ }^{* *} P<0.01$. The reported comparisons concern: $P$. noctiluca crude venom versus control (a), Fraction 1 versus control (a) and Fraction 2 versus control (a). Every concentration is compared with its equivalent in the other extract. Significant difference obtained with: ${ }^{*} P<0.05:{ }^{*} P<0.01$. 
screened for their analgesic and BuChE inhibitory activities (Figure 2).

Great progress has been made in the last 30 years toward understanding the neural substrates of pain and identifying novel molecular targets for analgesic drug development [37]. Acetic acid induced writhing method is a sensitive procedure in detecting analgesic effect of medicinal agents [38]. P. noctiluca crude venom and its fractions (F1 and F2) showed significant analgesic action compared to the reference drug acetyl salicylate of lysine (ASL). The fraction 2 was found to exhibit higher analgesic activity than fraction 1 against acetic acid induced pain in mice at two dose levels ( $1 \& 2 \mathrm{mg} / \mathrm{kg}$ b.w.), these doses were not toxic for mice.

Suganthi et al [17] reported that intraperitoneally administration of $200 \mathrm{mg} / \mathrm{kg}$ of Crambionella stuhalmanni and Chrysaora quinquecirrha extracts significantly inhibit acetic acid induced writhing in mice, the inhibition of writhing response and central nervous system depressing activity percentage were $35 \%, 55 \%$ and $90 \%$, 95\%.

The present results coincide with those reported by other authors who studied the analgesic property of Conus lentiginosus and C. mutabilis, which was 128 times more than that of paracetamol [39]. Shanmuganandam [40] reported the effectiveness of Conus figulinus venom on guinea pig skin as an infiltration anaesthetic agent. Salivary gland secretion of the gastropod Conus $s p$. is one of the most important venoms to possess analgesic property $[41,42]$.

It is, therefore, assumed that central mechanisms may be involved in the observed phenomenon since the extract could elicit activities against pain model. Agents that exhibit these activities are believed to act primarily on the central nervous system.

Stomolophus nomurai stings produce distinctive psychiatric signs and symptoms $[43,44]$. The brain operation experiments show that this organ can be affected by the venom of Chrysaora quinquecirrha. The biphasic action, an early disorientation followed by recovery then eventual death may indicate two separate neuro-active principles in the venom [45].

Neurotoxins are components of venoms that are specifically directed against the nervous system. The molecular variety of these substances extends from low molecular weight alkaloids to peptides and complex proteins [46]. In Cnidaria the neurotoxins have been the subject of numerous studies [11,12,47]. SanchezRodriguez et al [48] isolated a $120-\mathrm{kDa}$ protein from the cubomedusa Carybdea marsupialis with a strong neurotoxic activity on marine crabs (Ocypode quadrata).

The principal role of cholinesterase $(\mathrm{ChE})$ is the termination of nerve impulse transmission at the cholinergic synapses by rapid hydrolysis of acetylcholine (ACh). Inhibition of $\mathrm{ChE}$ serves as a strategy for the treatment of Alzheimer's disease (AD), senile dementia, ataxia, myasthenia gravis and Parkinson's disease [49,50].

In this study, the crude venom of $P$. noctiluca and its fractions (F1and F2) were tested to determine their ability as human BuChE inhibitors. The BuChE inhibition was determined using an adaptation of the method described by Ellman et al [25]. P. noctiluca crude venom, $\mathrm{F} 1$ and $\mathrm{F} 2$ exhibited moderate to good anti-BuChE activity. In fact, the best inhibitory activity was determined by the F 2, with an order of inhibition capacity: F2 > crude venom $>\mathrm{F} 1$.

In spite of the widespread occurrence of $\mathrm{AChE}$ in animals only a few AChE inhibitors from natural sources have been isolated. For example, polypeptide fasciculins from mamba venom [50] and an alkaloids such as physostigmine from ordeal or Calabar bean [51]. An ethanolic extract from a zoanthid crust coral Parazoanthus axinellae exhibited anticholinesterase activity [52].

The present study indicated that jellyfish $P$. noctiluca crude venom and its fractions contained peptides with specific cholinesterase inhibitory activities which might be responsible for some of the neurotoxic effects of the venom on animals and humans.

\section{Conclusions}

In summary, we have shown for the first time that $P$. noctiluca crude venom and its fractions displayed analgesic and anti-BuChE activities at different doses without inducing acute toxicity. In the light of the obtained results, $P$. noctiluca crude venom can be considered as an effective agent to treat pain and neurodegenerative disorders such as AD. In future experiments, studies with purified fractions of $P$. noctiluca venom peptides could be conducted for further pharmacological, biological and toxicological characterization, such as the research of the antibiotic properties.

\section{Abbreviations}

P. noctiluca: Pelagia noctiluca; F1: Fraction 1; F2: Fraction 2; ASL: Acetyl salicylate of lysine; BuChE: Butyrylcholinesterase; anti-

BuChE: Antibutyrylcholinestrasic; DO: Optical density; AD: Alzheimer's disease; ChE: Cholinesterase; ACh: Acetylcholine; AChE: Acetylcholinesterase..

\section{Competing interests}

The authors declare that they have no competing interests.

\section{Authors' contributions}

YA carried out the studies, acquired the data, performed the data analysis, and drafted the manuscript. AD played a major role in the experimental procedures of this study. HbM carried out the statistical analysis. HB revised the manuscript and SA involved in the design and organization of the study and interpreted the results. All authors have read and approved the final manuscript.

\section{Acknowledgements}

This research was funded by the Tunisian Ministry of Scientific Research and Technology through the Laboratory for Research on Biologically Compatible Compounds (LRSBC). 


\section{Author details}

'Laboratory for Research on Biologically Compatible Compounds (LRSBC), Faculty of Dentistry, Monastir university, Rue Avicenne, 5019, Monastir, Tunisia. ${ }^{2}$ Laboratory for Biotechnology and Bio Geo Resources Valorisation (LBVBGR), High Institute of Biotechnology of Sidi Thabet University of Manouba, 2020, Ariana, Tunisia. ${ }^{3}$ University of Jendouba, Cité AlFaeiz rue Jamil Boutheina, Jendouba 8100, Tunisia.

Received: 19 December 2011 Accepted: 13 May 2012

Published: 12 June 2012

\section{References}

1. Turk T, Kem WR: The phylum Cnidaria and investigations of its toxins and venoms until 1990. Toxicon 2009, 54:1031-1037.

2. Forsskal Medusae: Descriptiones Animalium, Animalium, avium, amphibiorum, piscium, insectorum, verminum. Postmortem autoris edidit carsten Niebuhr Hauniae 1775, 1:106-111.

3. Licandro P, Conway DVP, Daly Yahia MN, Fernandez de Puelles ML, Gasparini S, Hecq JH, Tranter P, Kirby RR: A blooming jellyfish in the northeast Atlantic and Mediterranean. Biol Lett 2010, 6:688-691.

4. Malej A, Malej A Jr: Invasion of the jellyfish Pelagia noctiluca in the northern Adriatic: a non-success story. In Aquatic Invasions in the Black, Caspian and Mediterranean Seas. Edited by Dumont H, Shiganova T, Niermann U. Dordrecht, The Netherlands: Kluwer Academic Publishers; 2004:273-285. Chapter 16.

5. Mariottini GL, Giacco E, Pane L: The mauve stinger Pelagia noctiluca (Forsskål, 1775). Distribution, ecology, toxicity and epidemiology of stings. Mar Drugs 2008, 6:496-513.

6. Doyle TK, De Haas H, Cotton D, Dorschel B, Cummins V, Houghton JDR, Davenport J, Hays GC: Widespread occurrence of the jellyfish Pelagia noctiluca in Irish coastal and shelf waters. J Plankton Res 2008, 30:963-968.

7. Kass-Simon G, Scappaticci AA: The behavioral and developmental physiology of nematocysts. Can J Zool 2002, 80:1772-1794.

8. Maretic Z: The bloom of jellyfish Pelagia noctiluca along the coasts of Pula and Istria 1977-1983, with special reference to epidemiology, clinics and treatment. In Workshop on Jellyfish Blooms in the Mediterranean, Athens, Greece. Edited by. .; 1984:83-87. 31 October-4 November 1983, UNEP: Athens, Greece.

9. Eno AE, Konya RS, Ibu JO: Biological properties of a venom extract from the sea anemone Bunodosoma cavernata. Toxicon 1998, 36:2013-2020.

10. Bruhn T, Schaller C, Schulze C, Sanchez-Rodriguez J, Dannmeier C, Ravens U, Heubach JF, Eckhardt K, Schmidtmayer J, Schmidt H, Aneiros A, Wachter E, Beress $L$ : Isolation and characterisation of five neurotoxic and cardiotoxic polypeptides from the sea anemone Anthopleura elegantissima. Toxicon 2001, 39:693-702.

11. Hinds MG, Zhang W, Anderluh G, Hansen PE, Norton RS: Solution structure of the eukaryotic pore-forming cytolysin equinatoxin II: implications for pore formation. J Mol Biol 2002, 315:1219-1229.

12. Helmholz H, Ruhnau C, Schütt C, Prange A: Comparative study on the cell toxicity and enzymatic activity of two northern scyphozoan species Cyanea capillata (L.) and Cyanea lamarckii (Péron \& Léslieur). Toxicon 2007, 50:53-64.

13. Ovchinnikova TV, Balandin SV, Aleshina GM, Tagaev AA, Leonova YF, Krasnodembsky ED, Men'shenin AV, Kokryakov VN: Aurelin, a novel antimicrobial peptide from jellyfish Aurelia aurita with structural features of defensins and channel-blocking toxins. Biochem Biophys Res Commun 2006, 348:514-523.

14. Thangaraj S, Bragadeeswaran S, Suganthi K, Sri-Kumaran N: Antimicrobial properties of sea anemone Stichodactyla mertensii and Stichodactyla gigantea from Mandapam coast of India. Asian Pac J Trop Biomed 2011, $1: 43-46$.

15. Williams GP, Babu S, Ravikumar S, Kathiresan K, Prathap SA, Chinnapparaj S, Marian MP, Alikhan SL: Antimicrobial activity of tissue and associated bacteria from benthic sea anemone Stichodactyla haddoni against microbial pathogens. J Environ Biol 2007, 28(4):789-793.

16. Otero-Gonzalez AJ, Magalhaes BS, Garcia-Villarino M, Lopez-Abarrategui C, Sousa DA, Dias SC, Franco OL: Antimicrobial peptides from marine invertebrates as a new frontier for microbial infection control. FASEB $J$ 2010, 24:1320-1334.

17. Suganthi K, Bragadeeswaran S, Kumaran NS, Thangaraj S, Balasubramanian T: Biological and pharmacological activities of jellyfish Crambionella stuhalmanni (Chun, 1896) and Chrysaora quinquecirrha (Desor, 1848). Int J Pharm Sci 2011, 3:230-236.

18. Hsieh YHP: Jellyfish as food. Hydrobiologia 2001, 451:11-17.

19. Arillo A, Burlando B, Carli A, Mariottini GL: Mitochondrial alteration caused by cnidarians toxins: a preliminary study. Boll Soc It Bio/ Sper 1994, 70:307-313.

20. Marino A, Morabito R, Pizzata T, La Spada G: Effect of various factors on Pelagia noctiluca (Cnidaria, Scyphozoa) crude venom-induced haemolysis. Comp Biochem Physiol A 2008, 151:144-149.

21. Bradford MM: A rapid and sensitive method for the quantification of microgram quantities of protein utilizing the principle of protein-dye binding. Anal Biochem 1976, 72:248-254.

22. Laemmli UK: Cleavage of structural proteins during the assembly of the head of bacteriophage T4. Nature 1970, 227:680-685.

23. Miller LC, Tainter ML: Estimation of the ED50 and its error by means of log probit graphic paper. Proc Soc Exp Biol Med 1944, 57:261-264.

24. Koster R, Anderson M, De Beer EJ: Acetic acid for analgesic screening. Fed Proc 1959, 18:418-420

25. Ellman GL, Courtney KD, Andres VJR, Feather-Stone RM: A new and rapid colorimetric determination of acetylcholinesterase activity. Biochem Pharmacol 1996, 7:88-95.

26. Ortega MG, Agnese AM, Cabrera JL: Anticholinesterase activity in an alkaloid extract of Huperzia saururus. Phytomed 2004, 11:539-543.

27. Noor AT, Fatima I, Ahmad I, Malik A, Afza N, lqbal L, Latif M, Khan SB: Leufolins A and B, Potent Butyrylcholinesterase-inhibiting Flavonoid Glucosides from Leucas urticifolia. Molecules 2007, 12:1447-1454.

28. Qasim SZ: In Advances in Aquatic Biology and Fisheries. Edited by Aravindan, Kumari SDR. India: University of Kerala; 1998:5-10.

29. Russell FE: Marine toxins and venomous and poisonous marine animals In Advances in Marine Biology. Edited by Blaxter JHS, Russell FS, Yonge CM. London: Academic Press; 1984:725.

30. Ayed Y, Chayma B, Hayla A, Abid S, Bacha H: Is cell death induced by nematocysts extract of medusa Pelagia noctiluca related to oxidative stress? Environ Toxicol 2011, doi:10.1002/tox.20740.

31. Ayed Y, Boussabbeh M, Zakhama W, Bouaziz C, Abid S, Bacha H: Induction of cytotoxicity of Pelagia noctiluca venom causes reactive oxygen species generation, lipid peroxydation induction and DNA damage in human colon cancer cells. Lipids Health Dis 2011, 10:232.

32. Ayed Y, Bouaziz C, Brahmi D, Zaid C, Abid S, Bacha H: Cell death in relation to DNA damage after exposure to the jellyfish Pelagia noctiluca nematocysts. Environ Toxicol 2012, doi:10.1002/tox.21762.

33. Nagai $H$, Takuwa $K$, Nakao M, Ito E, Miyake M, Noda M, Nakajima T: Novel proteinaceous toxins from the box jellyfish (sea wasp) Carybdea rastoni. Biochem Biophys Res Commun 2000, 275:582-588.

34. Chung JJ, Ratnapala LA, Cooke IM, Yanagihara AA: Partial purification and characterization of a hemolysin (CAH1) from Hawaiian box jellyfish (Carybdea alata) venom. Toxicon 2001, 39:981-990.

35. Marino A, La Spada G: Regulatory volume increase in nematocytes isolated from acontia of Aiptasia diaphana (Cnidaria, Anthozoa). Cell Mol Biol 2004, 50:533-542.

36. Olson CE, Heard MJ, Calton GJ, Burnett JW: Interrelationships between toxins: Studies on cross-reactivity between bacterial or animal toxins and monoclonal antibodies to two jellyfish venoms. Toxicon 1985, 23:307-316.

37. Layer TR, McIntosh JM: Conotoxins: Therapeutic Potential and Application. Mar Drugs 2006, 4:119-142

38. Hasan SMR, Hossain MM, Akter R, Jamila M, Mazumder MEH, Alam MA, Faruque A, Rana S, Rahman S: Analgesic activity of the different fractions of the aerial parts of Commelina benghalensis Linn. Int J Pharmacol 2010, 6:63-67.

39. Sakthivel A: Biomedicinal activity of Conus lentiginosus and Conus mutabilis from Mumbai coast [M. F. Sc., Dissertation]. CIFE Mumbai India $1999,: 60$.

40. Shanmuganandam P: Studies on the venom Conus fugulinus Linnaeus, (Mollusca: Gastropoda) from the south east coast of India [Ph.D. thesis] India: Annamalai University; 1995:214.

41. Spampinato S, Speroni E, Govani P, Pistacchio E, Pomagnoli C, Murani G: Effect of omega conotoxin and verapamil on antinociceptive, behavioural and thermoregulatory responses to opiods in the rat. Eur J Pharmacol 1994, 254:229-238.

42. Burnett JW: Medical aspects of jellyfish evenomation: pathogenesis, case reporting and therapy. Hydrobiologica 2001, 451:1-9. 
43. Mingliang Z: Study on jellyfish Stomolophus nomurai stings on Beidhe. Nat Med J China 1988, 9:499.

44. Ishikawa T, Vucenik I, Shamsuddin A, Niculescu F, Burnett JW: Two new actions of sea nettle (Chrysaora quinquecirrha) nematocyst venom: studies on the mechanism of actions on complement activation and on the central nervous system. Toxicon 2004, 44:895-9.

45. Hucho F: Toxins as tools in Neurochemistry. A new Chem Int Ed Engl 1995, 34:39-50.

46. Beress L, Bruhn T, Sanchez-Rodriguez J, Wachter E, Schweitz H: Sea anemone Toxins, acting on $\mathrm{Na}+$ channels and $\mathrm{K}+$ channels: isolation and characterization. In Methods and Tools in Biosciences and Medicine Animal Toxins. Edited by Rochat H, Martin-Eauclaire MF. Switzerland: Birkha user Verlag; 2000:31-56.

47. Sanchez-Rodriguez J, Torrens E, Segura-Puertas L: Partial purification and characterization of a novel neurotoxin and three cytolysins from box jellyfish (Carybdea marsupialis) nematocyst venom. Arch Toxicol 2006, 80:163-168.

48. Sokmen M, Angelova M, Krumova E, Pashova S, Ivancheva S, Sokmen A, Serkedjieva A: In vitro antioxidant activity of polyphenol extracts with antiviral properties from Geranium sanguineum L. Life Sci 2005, 76:2981-2993.

49. Atta-ur Rahman, Choudhary M: Bioactive natural products as a potential source of new pharmacophores a theory of memory. Pure Appl Chem 2001, 73:555-560.

50. Karlsson E, Mbugua PM, Rodriguez-lthurralde DJ: Fasciculins, anticholinesterase toxins from the venom of the green mamba, Dendroaspis angusticeps. J Physiol Paris 1984, 79:232-240.

51. Fraser TR: On the characters, actions and therapeutical uses of the ordeal bean of Calabar (Physosrigma venenosum, Balfour). Edin med J 1863, 9:235-248.

52. Turk T, Macek P, Suput D: Inhibition of acetylcholinesterase by a pseudozoanthoxanthin-like compound isolated from the zoanthid Parazoanthus axinellae (O. Schmidt). Toxicon 1995, 33(2):133-42.

doi:10.1186/1476-0711-11-15

Cite this article as: Ayed et al:: Analgesic and antibutyrylcholinestrasic activities of the venom prepared from the Mediterranean jellyfish Pelagia noctiluca (Forsskal, 1775). Annals of Clinical Microbiology and Antimicrobials 2012 11:15.

\section{Submit your next manuscript to BioMed Central and take full advantage of:}

- Convenient online submission

- Thorough peer review

- No space constraints or color figure charges

- Immediate publication on acceptance

- Inclusion in PubMed, CAS, Scopus and Google Scholar

- Research which is freely available for redistribution 